\title{
Analysis of the outcome of liver transplantation patients in india - a prospective observational study
}

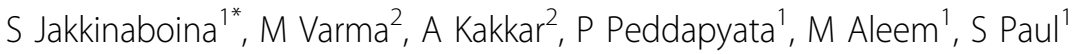 \\ From ESICM LIVES 2015 \\ Berlin, Germany. 3-7 October 2015
}

\section{Introduction}

Liver transplantation has become a widely accepted therapy for the management of the complications of cirrhosis and liver failure.

\section{Objectives}

To analyze the patients undergoing the Liver transplant Recipients and the factors influencing the outcome of the patients at our tertiary care hospital.

\section{Methods}

The patients underwent liver transplantation recepients between May 2014 to Jan 2015 were analysed. The data was collected from patient records after ethics committee approval. The data captured were Age,sex, ICU and hospital length of stay, bilirubin, albumin, INR, creatinine, intubation days, readmission,cold ischemia, warm ischemia, portal vein thrombosis, SGOT, SGPT, Vasopressors use, APACHE II, SOFA Score, MELD Score, arterial anatomy, graft complications, hospital and 60day mortality, readmissions, hospital acquired infections are monitored.

\section{Results}

The total number of patients enrolled are 34 . See tables 1 , 2 and 3

The hospital mortality rate in our study is $2.94 \%$ (one patient).

All the patients are ABO compatable, 2 patients had early graft rejection of which one patient liver functions has completely recovered and the other had not fully recovered. The hospital acquired infections are nil in these patients.

\footnotetext{
${ }^{1}$ Apollo Health City, Critical Care Medicine, Hyderabad, India Full list of author information is available at the end of the article
}

Table 1. Demographic data of the transplant receipients

\begin{tabular}{ll}
\hline Variable & Mean $\mathbf{n}(\%)$ \\
\hline Age in years & 49.5 \\
\hline Sex Male & $27(79.41)$ \\
\hline Cause of liver transplant (Alcohol cirrhosis) & $20(58.82)$ \\
\hline APACHE II at admission & 12.59 \\
\hline SOFA at admission & 7 \\
\hline MELD Score & 20.35 \\
\hline No Comorbidities & $26(76 \%)$ \\
\hline INR & 2.6 \\
\hline Total bilirubin $\mathrm{mg} / \mathrm{dl}$ & 4.51 \\
\hline
\end{tabular}

Table 2. Outcome data of transplant patients

\begin{tabular}{ll}
\hline Variable & Mean \\
\hline ICU length of stay in days & 4.85 \\
\hline Hospital length of stay in days & 15.18 \\
\hline Cold ischemia time in minutes & 243 \\
\hline Warm ischemia time in minutes & 45.06 \\
\hline Ventilator days & 0.85 \\
\hline Blood products received (PRBC) & 9.41 \\
\hline Albumin mg/dl & 2.91 \\
\hline Creatinine mg/dl & 1.23 \\
\hline Max SGOT U/L / Max SGPT U/L / Lowest Platelets 10/ & 1227 / 592 / \\
mm & 42.3 \\
\hline
\end{tabular}

$26(76.47 \%)$ liver donors are brain death patients. $5(14.71 \%)$ receipient patients are HCV positive. The factors increasing the the mortality are Increased ICU and hospital length of stay, reintubation, readmission and renal replacement therapy.

The statistically significant factors which increase the ICU length of stay are increased Bilurubin, decreased 
Table 3. Mortality and other outcomes of the patients

\begin{tabular}{lll}
\hline Variable & Number & Percentage \\
\hline Graft Whole / partial & $26 / 8$ & $76.5 / 23.5$ \\
\hline Mortality & 1 & 2.94 \\
\hline Arterial anatomy abnormality & 4 & 11.76 \\
\hline Renal Replacement therapy & 1 & 2.94 \\
\hline Vasopressors use & 5 & 14.71 \\
\hline Readmission & 2 & 5.89 \\
\hline Portal Vein Thrombosis & 2 & 5.89 \\
\hline
\end{tabular}

Albumin, increased ventilator days, increased Cold Ischemia and Warm Ischemia time, use of Vasopressors, lowest Platelets and raised INR.

The statistically significant factors which increase the Hospital length of stay are decreased Albumin, increased ventilator days, reintubation, use of Vasopressors, readmission and lower platelets. The 60 day mortality is similar to hospital mortality.

\section{Conclusions}

The patients undergoing the Liver transplant Recipients had good outcomes with less mortality and is comparable to the best centres in the world.

Hospital acquired infections are nil in these patients.

We need larger number to analyse the patients.

\section{Authors' details}

${ }^{1}$ Apollo Health City, Critical Care Medicine, Hyderabad, India. ${ }^{2}$ Apollo Health

City, Department of Hepatopancreatic Biliary Surgery, Hyderabad, India.

Published: 1 October 2015

\section{Reference}

1. Long-Term Survival After Liver Transplantation in 4,000 Consecutive Patients at a Single Center. Ann Surg 2000, 232(4):490-500, Oct.

doi:10.1186/2197-425X-3-S1-A697

Cite this article as: Jakkinaboina et al:: Analysis of the outcome of liver transplantation patients in india - a prospective observational study. Intensive Care Medicine Experimental 2015 3(Suppl 1):A697.

\section{Submit your manuscript to a SpringerOpen ${ }^{\mathcal{O}}$ journal and benefit from:}

- Convenient online submission

- Rigorous peer review

- Immediate publication on acceptance

- Open access: articles freely available online

- High visibility within the field

- Retaining the copyright to your article

Submit your next manuscript at $>$ springeropen.com 